\title{
Terapie genowe i genetyczne w chorobach nerwowo- mięśniowych wieku dziecięcego
}

\section{Gene and genetic therapies in neuromuscular diseases of childhood}

\author{
Małgorzata Jączak-Goździak* (iD), Barbara Steinborn* (iD) \\ *Oddział Kliniczny Neurologii Dzieci i Młodzieży, Szpital Kliniczny im. H. Święcickiego UM w Poznaniu, Katedra i Klinika Neurologii \\ Wieku Rozwojowego Uniwersytet Medyczny im. K. Marcinkowskiego w Poznaniu \\ ${ }^{* *}$ Katedra i Klinika Neurologii Wieku Rozwojowego UM im. K. Marcinkowskiego w Poznaniu, Oddział Kliniczny Neurologii Dzieci \\ i Młodzieży, Szpital Kliniczny im. H. Święcickiego UM w Poznaniu \\ DOI:10.20966/chn.2020.58.453
}

\section{STRESZCZENIE}

Osiągnięcia genetyki, biologii molekularnej i inżynierii genetycznej zrewolucjonizowały współczesną medycynę: umożliwiły poznanie i zrozumienie genetycznego podłoża wielu chorób i utorowały drogę do poszukiwania leczenia poprzez naprawę wadliwych genów. W ostatnich latach największe sukcesy w zakresie terapii genowej i genetycznej zostały osiągnięte $w$ chorobach nerwowo-mięśniowych wieku dziecięcego: w rdzeniowym zaniku mięśni i dystrofii mięśniowej Duchenne'a. To nowoczesne leczenie wykorzystuje różnorodne techniki takie jak: transport genów za pomocą wektorów wirusowych czy modyfikację ekspresji genów z użyciem antysensownych oligonukleotydów i „małych cząsteczek" oraz jeszcze badana, ale bardzo obiecującą, edycję genomu z zastosowaniem systemu CRISPR-Cas9. W pracy przedstawiono przegląd: przełomowych terapii w leczeniu SMA i DMD oraz leczenia genetycznego, badanego $w$ innych chorobach nerwowo- mięśniowych wieku dziecięcego

Słowa kluczowe: terapia genowa, modyfikacja splicingu, choroby nerwowo- mięśniowe.

\begin{abstract}
SUMMARY
The achievements in genetics, molecular biology and genetic engineering revolutionized modern medicine: they have made it possibile to know and understand the genetic basis of many diseases and have paved the way to seek treatment by reparing defective genes. In recent years, the greatest success in gene and genetic therapy have been achieved in neuromuscular diseases of childhood: spinal muscular atrophy and Duchenne muscular dystrophy. This cutting-edge treatment uses a variety of techniques such as: gene transport using viral vectors or modification of gene expression with the use of antisense oligonucleotides and "small molecules" as well as genome editing using the CRISPR-Cas9 system, still under investigation, but very promising. This article presents an overview of breakthrough therapies in the treatment of SMA and DMD and genetic treatment investigated in other neuromuscular diseases of childhood.
\end{abstract}

Key words: gene theraphy, splicing modification, neuromuscular diseases

\section{WSTĘP}

Osiągnięcia genetyki, biologii molekularnej i inżynierii genetycznej, jakie dokonały się w XX i na początku XXI wieku zrewolucjonizowały współczesną medycynę. Umożliwiły poznanie genetycznego podłoża wielu chorób a także zrodziły potrzebę znalezienia terapii dla tych schorzeń poprzez naprawę wadliwych genów.

Terapie genowe, $w$ tradycyjnym ujęciu, polegają na uzyskaniu efektu leczniczego poprzez wprowadzenie prawidłowego genu w miejsce brakującego lub zmutowanego [1]. W szerszym rozumieniu to nie tylko zastąpienie wadliwego genu, ale również jego naprawa a według niektórych badaczy wpływ na ekspresję zmutowanych genów [2].

Pierwsze badanie kliniczne wykorzystujące terapię genową przeprowadzono w 1990 roku w złożonym deficycie odporności (SCID) związanym z defektem deaminazy adenozyny [3]. A aktualnie, po ponad 30 latach od tego wydarzenia, w bazie badań klinicznych „clinicaltrials.gov” można znaleźć ponad 800 badań z zastosowaniem terapii genowych.

W neurologii wieku dziecięcego niewątpliwo największe osiągnięcia i postępy w leczeniu genowym dotyczą chorób nerwowo-mięśniowych. W ostatnich latach terapie genowe i genetyczne zostały zarejestrowane w leczeniu SMA oraz dystrofii mięśniowej Duchenna w USA oraz w Europie i będą coraz częściej spotykane w praktyce $[4,5]$. W poniższej pracy omówiono najczęstsze techniki stosowane w leczeniu genowym i genetycznym oraz przybliżono osiągnięcia w leczeniu schorzeń nerwowo- mięśniowych wieku dziecięcego.

W celu naprawy uszkodzonych genów, terapie genowe wykorzystują różnorodne techniki. Jedna ze stosowanych metod, opiera się na zastosowaniu wektorów wirusowych, czyli użyciu wirusów jako cząsteczek wprowadzających obce DNA do komórek gospodarza [6]. W terapiach genowych stosowane są wirusy $\mathrm{z}$ wielu rodzin, wykazujące tropizm do określonych tkanek, integrujące się (gammaretrowirus, lentiwirus) lub nieintegrujące się (adenowirus, adeno-associated wirus, herpes simplex virus) z genomem gospodarza [3]. Wektory wirusowe pierwszej generacji, najwcześniej badane, często doprowadzały do silnej reakcji zapalnej w organizmie gospodarza, niekiedy również uaktywniały onkogenezę, dlatego przez lata doświadczeń, wirusy zostały poddawane licznym modyfikacjom, tak 
aby działania niepożądane maksymalnie ograniczyć $[3,7]$. W chorobach układu nerwowego znalazły zastosowanie szczególnie pochodne adenowirusów tzw. AAV [1-3].

Innym, obiecującym narzędziem dla terapii genowych jest mechanizm CRISPR (clustered regularny interspaced short palindromic repeats)-Cas 9, określany jako tzw. precyzyjne nożyczki lub skalpel do genów, w którym główną rolę odgrywa jedna z nukleaz Cas9 [2,7]. System ten wykorzystuje elementy nabytej odporności bakterii na infekcję fagami i transformację obcym materiałem genetycznym. Mikroorganizmy włączają do loci CRISPR w swoim genomie fragmenty obcego DNA, co umożliwia w przyszłości szybkie rozpoznanie i zwalczenie infekcji [7,8]. W terapii genowej kompleks CRISPR-Cas9 składa się z 3 elementów:

1) RNA guide - nić komplementarna do fragmentu DNA ze zmutowanym genem gospodarza,

2) nukleazy - Cas 9 - umożliwiającej przecięcie nici DNA gospodarza w miejscu mutacji

3) właściwego fragmentu DNA, które ma zastąpić wycięty fragment $z$ mutacją $[7,9,10]$.

Pierwsze badania kliniczne z zastosowaniem tego mechanizmu są już prowadzone między innymi w zespole Angelmana [11]. Duże nadzieje dla CRISPR - Cas9 wiąże się szczególnie z możliwością leczenia chorób jednogenowych, których opisano ponad 10.000 [10]. Za opracowanie modelu edycji genomu CRISPR-Cas9 [7] badaczki Emmanuelle Charpentier i Jennifer A. Doudna otrzymały w 2020r. Nagrodę Nobla w dziedzinie chemii.

W szerokim rozumieniu do terapii genowych zalicza się techniki regulujące ekspresję genu poprzez zastosowanie antysensownych oligonukleotydów [2, 12, 13] lub tzw. małych cząsteczek "small molecules"[14]. Są to substancje, które nie wpływają bezpośrednio na wadliwy gen, ale regulują jego ekspresję poprzez działanie na syntezę białka. Antysensowne nukleotydy i małe cząsteczki łączą się z pre-mRNA regulują splicing (składanie genu), powodując włączenie lub wycięcie określonego eksonu w nici mRNA [2, 12, 14]. Cząsteczki te, klasyfikuję się niekiedy jako terapię genową ,niewirusową”[2] i bez wątpienia jako „modulatory” ekspresji genów należą do terapii genetycznych, ale zaliczanie ich do terapii genowych jest kontrowersyjne.

\section{RDZENIOWY ZANIK MIĘSNI (SMA)}

Rdzeniowy zanik mięsni to najczęstsza (1:7tys) uwarunkowana genetycznie, o dziedziczeniu autosomalnym recesywnym, choroba obwodowego układu nerwowego, rozpoczynająca się $\mathrm{w}$ dzieciństwie [15]. Występowanie SMA jest związane z mutację genu SMN - genu znajdującego się na chromosomie 5, warunkującego przeżycie motoneuronu [16]. U ludzi występują 2 kopie tego genu: telomerowa SMN1 i centromerowa SMN2. Za występowanie objawów klinicznych odpowiada mutacja SMN1, a gen SMN2 jest głównym modyfikatorem fenotypu [16] SMN2 może występować w kilku kopiach (0-6), im lżejszy przebieg tym więcej kopii SMN2 [15]. Oba geny SMN1 i SMN2 kodują jednakowe białko SMN [15]. Natomiast na skutek jednonukleotydowej różnicy w eksonie 7, gen SMN2 podlega alternatywnemu splicingowi, i większość produkowanego białka SMN jest niestabilna, tylko około $10-20 \%$ jest pełnowartościowa i odpowiadająca białku produkowanemu przez gen SMN1 [15]. U 95\% chorych na SMA występuje homozygotyczna delecja w SMN1, $\mathrm{w}$ pozostałych $5 \%$ delecja z patogenną mutacją punktową lub dwie mutacje punktowe [17]. Objawy kliniczne SMA to wiotkość, symetryczne, osłabienie siły mięśniowej, początkowo mięśni ksobnych i z przewagą kończyn dolnych, obserwuje się brak odruchów kolanowych lub uogólnioną arefleksję i drżenie palców [16]. Z postępem choroby może dochodzić do zajęcia wszystkich grup mięśni szkieletowych, do trudności z połykaniem i oddychaniem [17]. W tradycyjnym podziale wyróżnia się kilka postaci [4]:

SMA 0 - jedna kopia SMN2 - początek objawów w okresie noworodkowym, najczęściej śmierć przed 6 miesiącem życia na skutek powikłań oddechowych

SMA 1 - dwie do trzech kopii SMN2 - początek objawów przed 6 miesiącem życia, dzieci nie nabywają umiejętności samodzielnego siedzenia. Przed wprowadzeniem leczenia, okres przeżycia $\mathrm{w}$ tej grupie, z uwagi na rozwijającą się niewydolność oddechową, szacowano na 2 lata.

SMA 2 - najczęściej trzy kopie SMN2, dzieci nabywają umiejętność siedzenia, ale nie chodzą.

SMA 3 - trzy do czterech kopii SMN2, pacjenci nabywają umiejętność chodzenia, którą z czasem tracą, długość przeżycia prawidłowa.

SMA 4 - cztery i więcej kopii SMN2 - pierwsze objawy po 30 roku życia, przebieg łagodny, normalna długość życia.

W ostatnich latach do leczenia SMA zarejestrowano kilka terapii $[4,5]$. Mechanizmy działania nowych terapii w SMA zaprezentowano na rycinie 1

Ryc.1. Nowe terapie w SMA:

Fig.1. New therapies in SMA:

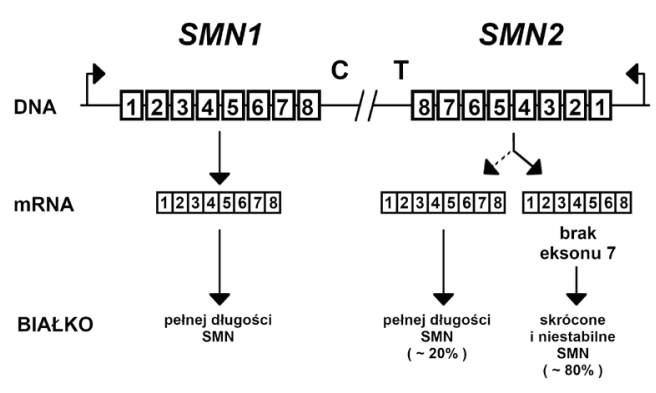

SMN terapia genowa

SMN2 modulacja splicingu

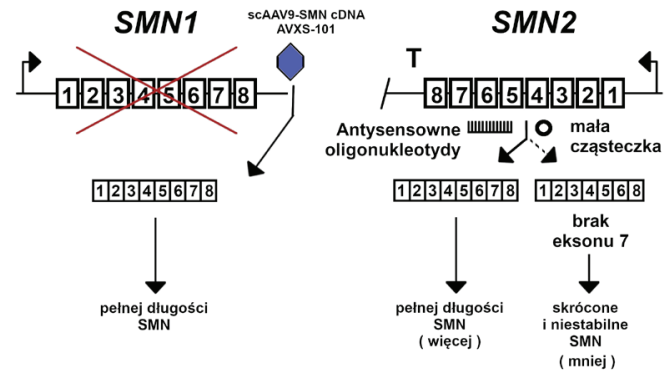


Pierwszym zatwierdzonym (przez FDA) lekiem w leczeniu SMA był nusinersen - czyli antysensowny oligonukleotyd, który poprzez modyfikację pre-mRNA doprowadza do włączenia exonu 7 do mRNA i w efekcie produkcję pełnowartościowego stabilnego biała SMN w większej ilości $[12,14]$. Lek został zarejestrowany w USA w grudniu 2016r. po zakończonych sukcesem badaniach klinicznych $[4,5]$. Badanie 3 fazy przeprowadzono u dzieci z SMA typu 1, w wieku od 1 miesiąca do 262 dni życia, u których pierwsze objawy wystąpiły przed 6 miesiącem życia. Pacjenci otrzymali $12 \mathrm{mg}$ nusinersenu dokanałowo podczas nakłucia lędźwiowego. Próbę zakończono wcześniej z powodu uwodnionej wysokoprocentowej (41\%) poprawy, ocenianej jako osiągniecie kamieni milowych w rozwoju ruchowym w skali Hammersmith Infant Neurological Examination (w całej grupie kontrolnej stwierdzono brak poprawy - 0\%) [4,17]. U 51\% leczonych dzieci wykazano zwiększone prawdopodobieństwo przeżycia powyżej 13 miesięcy.

Po sukcesie badania u dzieci z SMA 1 przeprowadzono również fazę 3 badania dla dzieci z typem 2 SMA w wieku od 2 do 9 lat. Po 15 miesiącach obserwacji, wykazano poprawę o 4 punkty w skali Hammersmith Functional Motor Scale Expanded u pacjentów poddanych terapii w porównaniu do spadku, w przybliżeniu o 1 punkt, w grupie kontrolnej [4]. U pacjentów z SMA3 w wieku miedzy 18 a 59 rokiem życia po 10 miesięcznej terapii w badaniu klinicznym, stwierdzono nieznaczną poprawę w 6 minutowym teście chodu: pacjenci byli w stanie przejść średnio $377.75 \mathrm{~m}$ na końcowej wizycie $\mathrm{w}$ stosunku do $369.5 \mathrm{~m}$ na wizycie baseline [4].

Nusinersen nie przenika bariery krew-mózg dlatego podawany jest dokanałowo podczas nakłucia lędźwiowego. Początkowo podaje się 4 dawki wysycające (dzień 1, 14, 28,63 ) a następnie kontynuacja polega na podawaniu jednej dawki co 3 miesiące $[4,14,18]$. Podczas terapii zalecane jest monitorowanie poziomu płytek krwi, układu krzepnięcia i kreatyniny [4]. Leczenie jest generalnie bezpieczne i dobrze tolerowane, ale w związku ze zmianami w układzie kostnym, u pacjentów z SMA (częste skolizy) niekiedy pojawiają się trudności z wykonaniem nakłucia lędźwiowego [4].

Lekiem o podobnym mechanizmie działania do nusinersenu jest risdiplam (Evrysdi ${ }^{\circledR}$ ), zarejestrowany do leczenia przez FDA w sierpniu 2020, w Europie oczekujący na rejestrację $[4,18]$. W Polsce dopuszczony tylko w ramach globalnego programu dostępu $[4,18]$. Risdiplam jest podawany codziennie w postaci syropu $[4,14]$. Jest to „mała cząsteczka", która podobnie jak nusinersen, powoduje wbudowywanie eksonu 7 do pre-mRNA i powstawanie w większej ilości stabilnego białka SMN [4, 14]. W próbie klinicznej z tą cząsteczką (badanie FIREFISH) przeprowadzonej u niemowląt z SMA1 w wieku od 1 do 7 miesięcy po 16 miesięcznej terapii: u 93\% pacjentów stwierdzono poprawę o 4 punkty w skali Children's Hospital of Philadelphia Infant Test of Neuromuscular Disorders. W starszych grupach wiekowych (od 2 do 25lat) u pacjentów z SMA 2 i SMA3 w obserwacji SUNFISH również sugeruje się poprawę funkcji ruchowych [4]. Aktualnie prowadzone są także ba- dania dla niemowląt przedobjawowych (RAINBOWFISH) i dla grupy pacjentów, którzy wcześniej byli leczeni innymi preparatami (JEWELFISH). Wyniki ostatnich badań wskazują, iż risdiplam nie jest toksyczny dla siatkówki u pacjentów z SMA i w trakcie leczenia nie są wymagane specjalne kontrole okulistyczne [19] (inaczej niż sugerowano po badaniach przeprowadzonych na zwierzętach).

Kolejnym modulatorem splicingu, obok risdiplamu i nusinersenu jest branaplam. Jest to lek, zaliczany do małych cząsteczek (podobne jak risdiplam), podawany drogą doustną. Aktualnie branaplam badany jest u pacjentów z SMA typu I w próbach klinicznych I i II fazy [14, 17].

W maju 2019 roku w USA zarejestrowano pierwszą terapię genową do leczenia SMA pod nazwą onasemnogene abeparvovec-xioi (Zolgensma $\left.{ }^{\circledR}\right)$ [4, 18]. Leczenie polega na jednokrotnym, dożylnym podaniu preparatu zawierającego fragment DNA, uzupełniającego gen SMN, umożliwiającego powstanie stabilnego białka SMN. Transgen czyli obcy materiał genetyczny (DNA odpowiadające genowi SMN) jest wprowadzane za pomocą wektora wirusowego - niereplikującego rekombinowanego związanego $\mathrm{z}$ adenowirusami wirusa serotypu 9 (scAAV9) będącego pod kontrolą cytomegalowirusowego wzmacniacza (enhacer/chicken- $\beta$-actin-hybrid promotor). Serotyp 9 AAV przekracza barierę krew mózg, a jego końcowe powtórzenie (ITR) zostało tak zmodyfikowane, aby promować wewnątrzcząsteczkową hybrydyzację transgenu, od razu gotowego do replikacji i transkrypcji. Jednokrotne podanie leku wynika ze zdolności komórek motoneuronu do długiego przeżycia i ich braku możliwości do podziału. W obserwacjach klinicznych fazy 1/2a u 15 dzieci z SMA1 i dwoma kopiami genu SMN2, leczonych pomiędzy 0.9 i 7.9 miesiącem życia zanotowano istotną poprawę w osiąganiu kamieni milowych w rozwoju motorycznym $[4,17]$. $\mathrm{Na} 12$ pacjentów otrzymujących większą dawkę (ramię z 2x10e14 vector genomes/na kg masy ciała): 11 osób było zdolnych do siedzenia bez podparcia przez $5 \mathrm{~s}, 9$ pacjentów przez 30s, 9 osób potrafiło przekręcać się, a 2 dzieci raczkowało i chodziło samodzielnie [4]. W dalszej obserwacji, po 2 latach od podania leku: 2 pacjentów dodatkowo samodzielnie siedziało przez 30 sekund, a 2 kolejnych stawało z pomocą. Dodatkowo 11/12 dzieci tolerowało przynajmniej częściowo doustne żywienie i mówiło pod koniec ocenianego okresu [4].

W związku z obserwowanymi, bezobjawowymi i przemijającymi wzrostami poziomów enzymów wątrobowych ALT i AST, do terapii genowej dodano prednisolon w dawce $1 \mathrm{mg} / \mathrm{kg}$ m.c przez $30 \mathrm{dni}$, począwszy od dnia poprzedzającego podanie leku [4].

Onasemnogene - abeparvotec - xioi został zarejestrowany do leczenia dla wszystkich pacjentów z SMA poniżej 2 roku życia(z wyłączeniem osób w końcowym stadium zaawansowania choroby) [4], ważących mniej niż 13,6 kg [5]. Przed podaniem leku wskazane jest badanie enzymów wątrobowych(ALT, AST), bilirubiny, czasu protrombinowego i płytek krwi [4]. Należy rozważyć również badanie serologiczne w kierunku HIV, WZW typu B i C. Oznacza się miano przeciwciał anty AAV9, a wartości powyżej 1: 50 są przeciwwskazaniem do terapii z wektorem AAV9 
[4]. Zaleca się również laboratoryjną ocenę Troponiny I, aby monitorować ewentualne działania niepożądane ze strony serca, których jednak nie wykazano w badaniach klinicznych [4]. Lek podawany jest w dawce $1.1 \times 10 \mathrm{e} 14 \mathrm{vg} / \mathrm{kg}$ podczas 60 minutowej infuzji dożylnej. Z działań niepożądanych najczęściej zgłaszane były wymioty i podwyższone poziomy enzymów wątrobowych, dlatego zaleca się ich kontrolę po tygodniu od infuzji. Opisywano również przemijające spadki poziomu płytek i wzrost troponiny I bez znaczenia klinicznego. Choć nie obserwowano aby wektor AAV9 wywoływał objawy jakiejkolwiek infekcji u człowieka, opiekunom pacjentów poddanych terapii genowej, zaleca się noszenie rękawiczek i dokładne przestrzeganie higieny rąk przez 4-6 tygodni, aby chronić przed ewentualnym tworzeniem przeciwciał przeciwko AAV9 (utrudniających w przyszłości terapię za pomocą tego wektora) [4]. Szczepienie u pacjentów mogą się odbywać do tygodnia przed terapią, a następnie szczepionki inaktywowane mogą być kontynuowane w dowolnym czasie. W przypadku szczepionek żywych atentowanych należy się powstrzymać do 4 tygodni od zakończenia terapii sterydami [4].

Onasmenogene- abeparvotec- xiomi jest nową bardzo obiecującą terapią, już zarejestrowaną, ale nad którą wciąż trwają badania kliniczne oraz obserwacje długoterminowe. W przyszłości na pewno będzie można jeszcze lepiej ocenić jej skuteczność.

Trwają również badania nad znalezieniem innej drogi podania leku, aby zmniejszyć dawkę i w ten sposób ograniczyć koszty [4,18]. Do lipca 2020 r. testowano podanie dokanałowe, jednak próby zostały wstrzymane $\mathrm{z}$ powodu obserwowanego zapalenia korzeni nerwowych w badaniach na zwierzętach [4,18]

Terapie genowe i genetyczne zarejestrowane w leczeniu SMA podsumowano w tabeli I (tab. I).

\section{LECZENIE GENOWE DYSTROFII MIĘŚNIOWEJ DUCHENNE (DMD)}

Dystrofia mięśniowa typu Duchenne’a jest poważną, degeneracyjną chorobą dziedziczoną w sposób recesywny sprzężony z płcią, o częstotliwości występowania od 1:3500-5000 żywo urodzonych chłopców [20]. Łagodniejszą fenotypowo formą choroby jest dystrofia mięśniowa Beckera. Obie jednostki są spowodowane mutacją w genie dystrofiny [15]. Jest to największy znany ludzki gen zbudowanym z 79 eksonów [20], odpowiadający za: produkcję strukturalnego białka łączącego cytoszkielet komórki mięśniowej z błoną komórkową oraz stabilizację błony komórkowej w czasie skurczu i rozkurczu mięśni [21]. W dystrofinie wyróżnia się 4 regiony; końcowy N, środkowy, region wzbogacony cysteiną i region końcowy $\mathrm{C}$ [21]. Dwie trzecie mutacji w tej dystrofii to duże delecje jednego lub więcej eksonów, pozostała jedna trzecia to insercje, małe delecje, mutacje punktowe i mutacje splicingu [20]. Dystrofia mięśniowa Duchenne'a jest spowodowana mutacją z zaburzeniem ramki odczytu (out of frame) i brakiem funkcjonalnej dystrofiny [15]. Natomiast w dystrofii mięśniowej Beckera stwierdza się mutację bez zaburzenia ramki odczytu (in frame) powstaje dystrofina, ale krótsza [15]. Początkowe objawy DMD pojawiają się u chłopców, zwykle między 2 a 5 rokiem życia i są to: opóźnienie rozwoju ruchowego, upadki, chód na palcach, przerost łydek, bardzo wysokie poziomy kinazy keratynowej, niekiedy lekka niepełnosprawność intelektualna [20]. Z czasem na skutek unieruchomienia pojawiają się deformacje klatki piersiowej, może rozwinąć się niewydolność oddechowa i zaburzenia krążenia [21].

W leczeniu dystrofii mięśniowej Duchenna i Beckera stosuje się sterydy [21,22]. Pierwsze wyniki badań wskazujące na korzyści leczenia prednizonem pacjentów z DMD opublikowano w 1974 roku [4, 22]. Wprowadzenie

Tab. I. Leki zatwierdzone w leczeniu SMA (na podstawie „Overview of gene therapy in spinal muscular atrophy and Duchenne muscular dystrophy" Abreu N., Waldrop M.) [4]

Tab. I. Drugs approved in the treatment of SMA (based on "Overview of gene therapy in spinal muscular atrophy and Duchenne muscular dystrophy" Abreu N., Waldrop M.) [4]

\begin{tabular}{|c|c|c|c|c|}
\hline $\begin{array}{c}\text { Lek } \\
\text { Treatment }\end{array}$ & $\begin{array}{l}\text { Mechanizm } \\
\text { Mechanism }\end{array}$ & $\begin{array}{l}\text { Droga podania } \\
\text { Method Of } \\
\text { Administration }\end{array}$ & $\begin{array}{c}\text { Data rejestracji } \\
\text { Fda } \\
\text { Fda approval date }\end{array}$ & $\begin{array}{l}\text { Ograniczenia } \\
\text { Limitation to use }\end{array}$ \\
\hline $\begin{array}{l}\text { Nusinersen } \\
\left.\text { (Spinraza }{ }^{\circledR}\right)\end{array}$ & $\begin{array}{c}\text { Antysensowny } \\
\text { oligonuklotyd } \\
\text { zmieniajacy splicing } \\
\text { SMN2 } \\
\end{array}$ & $\begin{array}{c}\text { Dokanałowo, } \\
4 \text { dawki wysycające, } \\
\text { następnie } 1 x / 4 \\
\text { miesiące }\end{array}$ & 23.12 .2016 & - \\
\hline $\begin{array}{l}\text { Onasemnogene } \\
\text { abeparvovec-xioi } \\
\text { (Zolgensma®) }\end{array}$ & $\begin{array}{l}\text { Terapia genowa za } \\
\text { pomocą wektora } \\
\text { wirusowego }\end{array}$ & Jedna iniekcja i.v. & 24.05 .2019 & $\begin{array}{l}\text { Poniżej } 2 \text { roku życia i z ostrożnością } \\
\text { dla zaawansowanej postaci SMA } \\
\text { (tetraplegia, potrzeba ciągłej } \\
\text { wentylacji). W Europie - rejestracja } \\
\text { dla dzieci z SMA poniżej } 21 \mathrm{~kg} \text { ( } \\
\text { poniżej } 5 \text { roku życia) i z obecnością } \\
\text { do } 3 \text { kopii genu SMN2) }\end{array}$ \\
\hline $\begin{array}{l}\text { Risdiplam } \\
\text { (Evrysdi®) }\end{array}$ & $\begin{array}{l}\text { Modyfikator splicing } \\
\text { SMN2 }\end{array}$ & Raz dziennie doustnie & 7.08 .2020 & Od 2 miesiąca życia \\
\hline
\end{tabular}


tej terapii zmieniło naturalny przebieg choroby: wydłużyło okres samodzielnego chodzenia, opóźniło czas wystąpienia zaburzeń oddechowych i kardiologicznych [21]. Ostatnie lata to bardzo intensywne badania nad nowymi terapiami genetycznymi i genowymi, umożliwiającymi uzyskanie funkcjonalnej dystrofiny [4, 20]. Aktualnie najczęściej wykorzystuje się możliwość zablokowania/zakrycia kodonu stop przez antysensowne oligonukletydy i przekształcenie mutacji out of frame, w mutację in frame [4]. Jest to tzw. technika exon skipping, która pozwala na syntezę krótszej, ale funkcjonalnej dystrofiny, w odróżnieniu do całkowitego braku tego białka w przypadku mutacji typu out of frame (ryc. 2) [23].

Ryc.2. Mutacja „out of frame" w DMD i technika „exon skipping":

Ryc.2. "Out of frame" mutation in DMD and „exon skipping” technique:
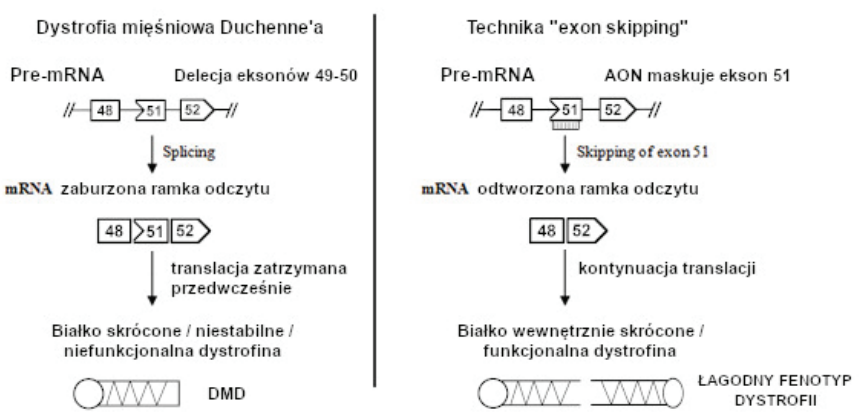

Pierwszym zarejestrowanym przez FDA w leczeniu DMD lekiem był 2016 r. i był to antysensowny oligonu- kleotyd - eteplirsen [4,20]. Do chwili obecnej zarejestrowano kolejne 2 preparaty (Tab. II) [4]. Pominiecie eksonów jest możliwe w 80\% mutacji w DMD [18]. Eteplirsen umożliwia zakrycie eksonu 51 i leczenie około $13 \%$ chorych z DMD [20], pacjentów z delecjami 45-50, 48-50, 50 i 52 [21]. Lek podawany jest dożylnie raz w tygodniu [4]. W badaniach klinicznych u pacjentów leczonym etepliresenem wykazano wzrost poziomu dystrofiny o $23 \%$, poprawę dystansu w teście 6-minutowego chodu, a wydolność oddechowa dłużej pozostawała stabilna. Pozostałe zarejestrowane cząsteczki to golidersen (2019r.) i vitolarsen (2020r.), obie umożliwiające zasłonięcie eksonu 53, podawane są drogą dożylną, raz w tygodniu [4]. W badaniach klinicznych tych preparatów wykazano: wzrost ekspresji dystrofiny u pacjentów leczonych, a w przypadku vitolarsenu stwierdzono znaczną poprawę sprawności, ocenianą pomiarem czasów: zmiany pozycji z leżącej na stojącą oraz przejściem 10 metrów [4].

Około 10-15\% DMD jest spowodowane przez mutację typu nonsense, która tworząc kodon stop, przedwcześnie kończy syntezę dystrofiny. Ataluren jest lekiem o punkcie uchwytu tłumiącym kodon stop, co umożliwia powstanie częściowo funkcjonalnej dystrofiny $[15,20]$. Jest to strukturalnie „mała cząsteczka”, jako preparat podawana doustnie, 3 razy na dobę [18]. Lek został zarejestrowany w Europie po badaniu klinicznym 2 fazy, w którym wykazano wzrost ekspresji dystrofiny. Natomiast w USA nie został zatwierdzony do użycia przez FDA z powodu obserwacji 3 fazy, w której nie wykazano poprawy w teście 6 minutowego chodu [20].

Leki zarejestrowane w leczeniu DMD podsumowano w tabeli II ( Tab. II).

Tab. II. Leki zatwierdzone w leczeniu DMD (na podstawie „Overview of gene therapy in spinal muscular atrophy and Duchenne muscular dystrophy" Abreu N., Waldrop M.) [4]

Tab. II. Drugs approved in the treatment of DMD (based on "Overview of gene therapy in spinal muscular atrophy and Duchenne muscular dystrophy" Abreu N., Waldrop M.) [4]Duchenne muscular dystrophy" Abreu N., Waldrop M.) [4]

\begin{tabular}{|c|c|c|c|c|}
\hline $\begin{array}{l}\text { Lek } \\
\text { Treatment }\end{array}$ & $\begin{array}{l}\text { Mechanizm } \\
\text { Mechanism }\end{array}$ & $\begin{array}{l}\text { Droga podania } \\
\text { Method Of } \\
\text { Administration }\end{array}$ & $\begin{array}{c}\text { Data rejestracji } \\
\text { Fda } \\
\text { Fda approval date }\end{array}$ & $\begin{array}{l}\text { Ograniczenia } \\
\text { Limitation to use }\end{array}$ \\
\hline Eteplirsen (Exondys51®) & $\begin{array}{c}\text { Antynsensowy } \\
\text { oligonukleotyd } \\
\text { powodujący } \\
\text { ominięcie exonu } 51 \\
\end{array}$ & $\begin{array}{l}\text { Jedna iniekcja i.v. } \\
1 \mathrm{x} / \text { na tydzień }\end{array}$ & 19.09 .2016 & $\begin{array}{c}\text { DMD z mutacjami } \\
\text { w których pominięcie } \\
\text { eksonu } 51 \text { prowadzi } \\
\text { do syntezy dystrofiny }\end{array}$ \\
\hline $\begin{array}{c}\text { Golodirsen } \\
\text { (Vyondys53®) }\end{array}$ & $\begin{array}{l}\text { Antynsensowy } \\
\text { oligonukleotyd } \\
\text { powodujący } \\
\text { ominięcie exonu } 53\end{array}$ & $\begin{array}{l}\text { Jedna iniekcja i.v. } \\
\text { 1x/ na tydzień }\end{array}$ & 12.12 .2019 & $\begin{array}{l}\text { DMD z mutacjami } \\
\text { w których pominięcie } \\
\text { eksonu } 53 \text { prowadzi } \\
\text { do syntezy dystrofiny }\end{array}$ \\
\hline $\begin{array}{l}\text { Viltolarsen } \\
\left.\text { (Viltepso }{ }^{\circledR}\right)\end{array}$ & $\begin{array}{c}\text { Antynsensowy } \\
\text { oligonukleotyd } \\
\text { powodujący } \\
\text { ominięcie exonu } 53\end{array}$ & $\begin{array}{l}\text { Jedna iniekcja i.v. } \\
\text { 1x/ na tydzień }\end{array}$ & 12.08 .2020 & $\begin{array}{c}\text { DMD z mutacjami } \\
\text { w których pominięcie } \\
\text { eksonu } 53 \text { prowadzi } \\
\text { do syntezy dystrofiny }\end{array}$ \\
\hline $\begin{array}{c}\text { Ataluren } \\
\left(\text { Translarna }{ }^{\circledR}\right)\end{array}$ & $\begin{array}{c}\text { Mała cząsteczka } \\
\text { pozwalająca pominąć } \\
\text { przedwczesny kodon } \\
\text { stop }\end{array}$ & $3 x$ dziennie doustnie & $\begin{array}{l}\text { Zatwierdzony jedynie } \\
\text { w Europie }\end{array}$ & $\begin{array}{l}\text { Mutacja typu } \\
\text { nonsense }\end{array}$ \\
\hline
\end{tabular}


Poza wspomnianymi preparatami już zarejestrowanymi, kilka terapii jest $\mathrm{w}$ fazie intensywnych badań klinicznych m.in. terapia genowa $\mathrm{z}$ użyciem wektorów wirusowych. Gen dystrofiny jest bardzo dużym genem (11.5kb) i jego wielkość przekracza możliwości nośnikowe wektora wirusowego $(5 \mathrm{~kb})[22,24]$, dlatego w terapii genowej testuje się mikrodystrofinę, materiał genetyczny zawierającą fragmenty genu dystrofiny: końcówka $\mathrm{N}$ i C połączone różnymi fragmentami wstawkowymi $[22,24]$. Taki zmodyfikowany gen dystrofiny ma umożliwić syntezę białka o funkcjonalności dystrofiny [22]. Aktualnie badane są 3 terapie genowe z użyciem mikrodystrofiny różniące się serotypem AAV, promotorem i kryteriami włączenia [22,25]: AAVrh74 kapsyd z promotorem MHCK7, AAV9 kapsyd z promotorem CK8 i AAV9 kapsyd ze specyficznym mięśniowym promotorem. W jednym $z$ badań fazy $1 / 2 \mathrm{a} z$ użyciem wektora AAVrh74 z promotorem MHCK 7 u 4 pacjentów po transferze genu, po 12 tygodniach zanotowano wysokie poziomy ekspresji mikrodystrofiny, a po roku od terapii: poprawę funkcji ruchowych, obniżenie poziomu CK i wzrost o 2 punkty w skali oceniającej chód (North Star Ambulatory Assessment) w porównaniu do stanu wyjściowego. Leczenie było bezpieczne, z działań niepożądanych zgłaszano samoograniczające się wymioty i obserwowano przejściowe wzrosty enzymów wątrobowych. Na pełne wyniki badań należy jeszcze poczekać [4].
Alternatywą dla terapii genowej za pomocą mikrodystrofiny może być terapia genowa zastępcza, w której wpływa się na inne geny aby uzyskać efekt podobny jak dla genu dystrofiny [22]. Białkiem podobnym w budowie i spełnianych funkcjach jest utrofina [15], obecna w życiu płodowym i podczas regeneracji mięśni, a poza tym okresem wykrywana w złączach nerwowo-mięśniowych $[21,22]$. Terapia zastępcza ma wpływać na gen GALGT2, kodujący O-mannozyltransferazę dzięki której dochodzi do glikozylacji i powstawania kompleksów białkowych $\mathrm{z}$ utrofiną $\mathrm{w}$ połączeniach nerwowo- mięśniowych i ścięgnach. W badaniach na modelach zwierzęcych, modyfikacja genowa i wywołanie nadekspresji GALGT2 prowadzi do wzrostu poziomu utrofiny w całym mięśniu i poprawy funkcji mięśnia sercowego u myszy [22, 26].

Ogromne nadzieje w leczenie DMD wiąże się z systemem CRISPR-Cas9, pozwalającym na wycięcie jednego lub kilku eksonów i w ten sposób otwarcie ramki odczytu (24). Ta terapia obecnie jest badana na modelach zwierzęcych $[20,22,27]$

W przypadku pozostałych chorób nerwowo- mięśniowych nie ma jeszcze zarejestrowanego leczenia genowego czy genetycznego. Trwają badania różnej fazy nad leczeniem w dystrofiach obręczowo-kończynowych, w dystrofii miotonicznej, miopatiach wrodzonych, Chorobie Pompego i neuropatii Charcot-Marie-Tooth typ1A. Te próby leczenia omówiono w tabeli nr III.

Tab. III. Terapie genetyczne badane w chorobach nerwowo-mięśniowych:

Tab. III. Genetic therapies investigated in neuromuscular diseases:

\begin{tabular}{|c|c|c|c|c|}
\hline $\begin{array}{l}\text { Choroba } \\
\text { Disease }\end{array}$ & $\begin{array}{c}\text { Etiopatogeneza } \\
\text { Ethiopathogenesis }\end{array}$ & $\begin{array}{l}\text { Objawy kliniczne } \\
\text { Clinical symtoms }\end{array}$ & $\begin{array}{c}\text { Proponowane leczenie } \\
\text { Proposed Treatment }\end{array}$ & $\begin{array}{c}\text { Faza badań } \\
\text { Clinical } \\
\text { trials } \\
\text { Phase }\end{array}$ \\
\hline $\begin{array}{c}\text { Dystrofie } \\
\text { obręczowo- } \\
\text { kończynowe } \\
\text { LGMD }\end{array}$ & $\begin{array}{c}\text { Heterogenna grupa pod } \\
\text { względem genetycznym. } \\
\text { Wyróżnia się } 2 \text { grupy z uwagi na } \\
\text { sposób dziedziczenia: } \\
\text { 1.autosomalnie dominujące } \\
\text { LGMD1 (5-10\% wszystkich } \\
\text { LGMD) } \\
\text { 2.autosomalnie recesywne } \\
\text { LGMD2. } \\
\text { Podłoże genetyczne związane } \\
\text { jest z mutacją w jednym z białek } \\
\text { kodujących białka strukturalne } \\
\text { mięśnia: dysferylina (LGMD2B) } \\
\text { sarkoglikany (LGMD2C, LGMD2D, } \\
\text { LGMD2E) } \\
\text { Teletonina (LGMD2G) } \\
\text { lub białka enzymatyczne komórki } \\
\text { mięśniowej: } \\
\text { kalpaina (LGMD2A)[28 }\end{array}$ & $\begin{array}{l}\text { Heterogenna grupa } \\
\text { również pod względem } \\
\text { klinicznym, wspólne } \\
\text { objawy to osłabienie } \\
\text { siły mięśniowej } \\
\text { i zanik mięśni obręczy } \\
\text { biodrowej i barkowej } \\
\text { oraz mięśni ksobnych, } \\
\text { w niektórych } \\
\text { dystrofinach zajęte } \\
\text { również mięsnie } \\
\text { dystalne [28]. } \\
\text { Występują zazwyczaj } \\
\text { podwyższone poziomy } \\
\text { kinazy keratynowej (CK) } \\
\text { [18,20] }\end{array}$ & $\begin{array}{c}\text { 1Terapie genowe: } \\
\text { AAVrh7 beta-sarcoglycan } \\
\text { (LGMD2E/R4) } \\
\text { AAVrh74 alpha- sarcoglycan } \\
\text { (LGMD2D/R3) } \\
\text { AAV1 gamma-sarcoglycan } \\
\text { (LGMD2C/R5) } \\
\text { Dual AAVrh74 dysferylin } \\
\text { (LGMD2B/R2) } \\
\text { [18,25,29] }\end{array}$ & $\begin{array}{l}\text { Faza II } \\
\text { Faza I } \\
\text { Faza I } \\
\text { [18] }\end{array}$ \\
\hline
\end{tabular}




\begin{tabular}{|c|c|c|c|c|}
\hline $\begin{array}{c}\text { Dystrofia } \\
\text { miotoniczna } \\
\text { typ I } \\
\text { (postać } \\
\text { klasyczna) }\end{array}$ & $\begin{array}{c}\text { Choroba autosomalnie } \\
\text { dominująca z mutacją } \\
\text { w genie DMPK na chromosomie } \\
\text { 19q13.3 polegająca na ekspansji } \\
\text { powtórzeń CTG. Mutacja } \\
\text { o charakterze dynamicznym } \\
\text { - w kolejnych pokoleniach } \\
\text { choroba ujawnia się wcześniej } \\
\text { i ma cięższy przebieg } \\
\text { [28] }\end{array}$ & $\begin{array}{l}\text { Objawy ze strony wielu } \\
\text { mięśni i tkanek: } \\
\text { osłabienie i zanik } \\
\text { w pierwszej kolejności } \\
\text { mięśni dystalnych } \\
\text { kończyn i twarzy } \\
\text { (szczupłe dłonie, } \\
\text { przedramiona i podudzia, } \\
\text { pociągła twarz opadanie } \\
\text { powiek, zanik mięsni } \\
\text { skroniowych, } \\
\text { zaburzenia hormonalne } \\
\text { (nadczynność lub } \\
\text { niedoczynność tarczycy, } \\
\text { obniżone stężenie } \\
\text { testosteronu) } \\
\text { zaburzenia metaboliczne } \\
\text { (cukrzyca, hyperlidemia) } \\
\text { zaćma, zaburzenia } \\
\text { kardiologiczne } \\
\text { (zaburzenia } \\
\text { przewodnictwa, } \\
\text { kardiomiopatia) [28] }\end{array}$ & $\begin{array}{c}\text { Modyfikacja splicingu: } \\
\text { Metformina } \\
\text { Modulacja RNA: } \\
\text { Tideglusib } \\
\text { (inhibitor GSK-3 ) sprzyjający } \\
\text { redukcji toksycznego mRNA } \\
\text { zawierającego powtórzenie } \\
\text { CUG na skutek mutacji } \\
\text { DMPK } \\
\text { [18,30] }\end{array}$ & $\begin{array}{l}\text { Faza II } \\
\text { Faza II } \\
\text { [18] }\end{array}$ \\
\hline $\begin{array}{l}\text { Wrodzone } \\
\text { miopatie }\end{array}$ & $\begin{array}{c}\text { Zróżnicowana genetycznie grupa } \\
\text { chorób mięśniowych. } \\
\text { W próbach klinicznych aktualnie } \\
\text { badane są terapie dla: } \\
\text { Miopatii miotubularnej } \\
\text { (recesywna sprzężona z X) } \\
\text { Miopatii centro nuklearnej } \\
\text { związanej z mutacją w genie } \\
\text { DNM dynaminy (autosomalnie } \\
\text { dominująca) } \\
{[18]}\end{array}$ & $\begin{array}{c}\text { Wiotkość } \\
\text { Osłabienie siły } \\
\text { mięśniowej, dysmorfia } \\
\text { twarzy: długa, wąska } \\
\text { twarz, ,senny" wygląd. } \\
\text { W ciężkich postaciach; } \\
\text { niewydolność } \\
\text { oddechowa, skórcowny } \\
\text { okres przeżycia } \\
\text { Dysmorfie kostne; } \\
\text { gotyckie podniebienie, } \\
\text { zniekształcenie klatki } \\
\text { piersiowej, skolioza } \\
\text { [16] }\end{array}$ & $\begin{array}{c}\text { Terapia genowa } \\
\text { w miopatii miotubularnej } \\
\text { AAV8 Myotubular myopathy } \\
\text { Modyfikacja splicingu } \\
\text { w miopatii centronuklearnej } \\
\text { z mutacją dynaminy } \\
\text { DYN101 Dynamin -2 } \\
\text { [18] }\end{array}$ & $\begin{array}{l}\text { Faza II } \\
\text { Faza II } \\
\text { [18] }\end{array}$ \\
\hline $\begin{array}{l}\text { Choroba } \\
\text { Pompego } \\
\text { Glikogenoza } \\
\text { typu II }\end{array}$ & $\begin{array}{l}\text { Niedobór kwaśnej maltazy, } \\
\text { enzymu lizosomalnego. } \\
\text { Choroba dziedziczona } \\
\text { autosomalnie recesywnie. } \\
\text { Mutacja w genie kwaśniej } \\
\text { maltazy na chromosomie 17q23. } \\
\text { Poznano ponad } 60 \text { mutacji } \\
\text { i delecji w genie. W zależności } \\
\text { od typu i umiejscowienia mutacji } \\
\text { wyróżnia się różne postacie } \\
\text { kliniczne } \\
{[21]}\end{array}$ & $\begin{array}{l}\text { Postać niemowlęca: } \\
\text { dzieci rodzą się } \\
\text { wiotkie, szybko rozwija } \\
\text { się kardiomegalia, } \\
\text { hepatomegalia, } \\
\text { niewydolność } \\
\text { oddechowa } \\
\text { Postać młodzieńcza: } \\
\text { osłabienie mięśni } \\
\text { przykręgosłupowych } \\
\text { i przykurcze stawowe. } \\
\text { Postacie późne: } \\
\text { osłabienie mięśni } \\
\text { obręczy biodrowej } \\
\text { i barkowej } \\
\text { z podwyższonym } \\
\text { poziomem CK } \\
\text { [16] }\end{array}$ & $\begin{array}{c}\text { Terapia genowa za pomocą } \\
\text { AAV } \\
{[18]}\end{array}$ & $\begin{array}{c}\text { Badania } \\
\text { przed } \\
\text {-kliniczne } \\
\text { i fazy I } \\
\text { [18] }\end{array}$ \\
\hline
\end{tabular}




\begin{tabular}{|c|c|c|c|c|}
\hline $\begin{array}{c}\text { Choroba } \\
\text { Charcot-Marie- } \\
\text { Tooth'a } \\
\text { heterogenna } \\
\text { klinicznie } \\
\text { i genetycznie } \\
\text { grupa neuropatii } \\
\text { ruchowo- } \\
\text { czuciowych } \\
\text { najczęstsza } \\
\text { forma to } \\
\text { CMT1A (60\%) } \\
{[18]}\end{array}$ & $\begin{array}{c}\text { CMT1A jest chorobą } \\
\text { autosomalnie dominująca, } \\
\text { spowodowana duplikacją w genie } \\
\text { PMP22-białka obwodowego } \\
\text { mieliny } \\
\text { Nadekspresja PMP22 prowadzi } \\
\text { do demielinizacji i niewłaściwej } \\
\text { remielinizacji prowadzącej } \\
\text { do zwolnienia prędkości } \\
\text { przewodzenia w nerwach } \\
\text { a następnie wtórnego } \\
\text { aksonalnego zwyrodnienie [18] }\end{array}$ & $\begin{array}{c}\text { Deficyty czuciowe } \\
\text { i postępujące osłabienie } \\
\text { sity mięśniowej mięśni } \\
\text { grup dystalnych, } \\
\text { deformacje stóp i rąk. } \\
\text { [18] }\end{array}$ & $\begin{array}{c}\text { Terapia genowa z AAV1 } \\
\text { z genem neurotrofiny 3(NT-3) } \\
\text { AAV1.tMCK.NTF3 [18] } \\
\text {-terapia genowa „promująca } \\
\text { regenerację w CMT1A”[31] } \\
\text { wykorzystująca } \\
\text { zaangażowanie neurtrofiny } \\
\text { we wspieranie, przeżycie } \\
\text { i wzrost komórek Schwanna } \\
\text { oraz regenerację nerwów } \\
\text { obwodowych. } \\
\text { Modyfikacja splicingu za } \\
\text { pomocą antysensownych } \\
\text { oligonukleotydów } \\
\text { ( redukcja nadekspresji genu } \\
\text { PMP2)[14,18] }\end{array}$ & $\begin{array}{c}\text { Faza } 2 \\
\text { Badania } \\
\text { przed } \\
\text {-kliniczne } \\
\text { [18] }\end{array}$ \\
\hline
\end{tabular}

\section{PODSUMOWANIE}

Rozwój badań genetycznych umożliwił poznanie podłoża wielu chorób nerwowo- mięśniowych wieku dziecięcego, a następnie zainspirował do poszukiwania skutecznych sposobów leczenia za pomocą inżynierii genetycznej. Terapie genowe i genetyczne dają ogromną nadzieję na możliwość leczenia chorób dotychczas nieuleczalnych. Jest to terapia nowa (stosowana w praktyce w SMA i DMD dopiero od kilku lat) i na pełną ocenę skuteczności należy jeszcze poczekać. Jednakże w obliczu tej realnej możliwości leczenia w SMA i DMD, aktualnie wyzwaniem dla medycyny staje się wdrożenie badań przesiewowych noworodków oraz opracowanie systemu finansowania dla tych bardzo kosztownych terapii.

\section{PIŚMIENNICTWO}

[1] Nowak J., Januszkiewicz-Lewandowska D.: Perspektywy terapii genowe chorób neurologicznych. Adv Psychiatry Neurol., 1997; 6: 61-65.

[2] Renthal W.: Genomics to Gene Therapy in Neurology. Practical Neurology, 2019;18: 88-91.

[3] Flotte T.: Gene therapy: The first two decades and the current state of the art. J. Cell. Physiol., 2007; 213: 301-305.

[4] Abreu N., Waldrop M.: Overview of gene therapy in spinal muscular atrophy and Duchenne muscular dystrophy. Pediatr Pulmonol. 2020; 10: 1002

[5] Braun S.: Thérapies géniques de l'amyotrophie spinale infantile - Un morceau d'histoire de la médecine [Gene-based therapies of spinal muscular atrophy: a piece of history of medicine]. Med Sci, 2020; 36: $141-146$.

[6] Drewa G., Ferenc T.[red.],: Podstawy genetyki dla studentów i lekarzy. Urban \&Partner Wroctaw 2003: 406.

[7] Dunbar C., High K., Joung J., et al.: Gene therapy comes of age. Science, 2018: 359(6372): eaan4672

[8] Czarnek M., Bereta J.: System CRISPR-Cas - od odporności bakterii do inżynierii genomowej, Postepy Hig Med. Dosw 2016; 70: 901-916.

[9] Gonçalves G., Paiva R. :Gene therapy: advances, challenges and perspectives. Einstein (Sao Paulo). 2017; 15: 369-375.

[10] Memi F., Ntokou A., Papangeli I.: CRISPR/Cas9 gene-editing: Research technologies, clinical applications and ethical considerations. Semin in Perinatol. 2018; 42: 487-500.

[11] Wolter J., Mao H., Fragola G., et al.: Cas9 gene therapy for Angelman syndrome traps Ube3a-ATS long non-coding RNA. Nature. 2020; 587: 281-284.
[12] Li 0.: Nusinersen as a Therapeutic Agent for Spinal Muscular Atrophy. Yonsei Med J. 2020; 61: 273-283.

[13] Bennett C., Krainer A., Cleveland D.: Antisense Oligonucleotide Therapies for Neurodegenerative Diseases. Annu Rev Neurosci. 2019; 42: 385-406.

[14] Ravi B., Antonellis A., et al.: Genetic approaches to the treatment of inherited neuromuscular diseases. Hum Mol Genet. 2019; 28(R1): R55-R64.

[15] Jędrzejwska M.: Próby terapeutyczne w dystrofii mięśniowej typu Duchenne'a i rdzeniowym zaniku mięśni. Polski Przegląd Neurologiczny. 2010; 6, suplement A:34-35

[16] Steinborn B.[red.], Neurologia wieku rozwojowego. PZWL Warszawa 2017: 719-720, 724, 726.

[17] Waldrop M., Kolb S.: Current Treatment Options in Neurology-SMA Therapeutics. Curr Treat Options Neurol. 2019; 21: 25.

[18] Flotats-Bastardas M., Hahn A.: New Therapeutics Options for Pediatric Neuromuscular Disorders. Front Pediatr. 2020; 8: 583877.

[19] Sergott R., Amorelli G., Baranello G., et al.: Risdiplam treatment has not led to retinal toxicity in patients with spinal muscular atrophy. Ann Clin Transl Neurol. 2020; 8: 54-65.

[20] Datta N, Ghosh P.: Update on Muscular Dystrophies with Focus on Novel Treatments and Biomarkers. Curr Neurol Neurosci Rep. 2020; 20: 14.

[21] Hausmanowa- Petrusewicz I. [red.], Choroby nerwowo- mięśniowe. Wyd. II. Wydawnictwo Czelej Lublin 2013: 26-38.

[22] Waldrop M., Flanigan K.: Update in Duchenne and Becker muscular dystrophy. Curr Opin Neurol. 2019; 32: 722-727.

[23] Echevarría L., Aupy P., Goyenvalle A.: Exon-skipping advances for Duchenne muscular dystrophy. Hum Mol Genet. 2018; 27: R163-R172.

[24] Duan D.: Systemic AAV Micro-dystrophin Gene Therapy for Duchenne Muscular Dystrophy. Mol Ther. 2018; 26: 2337-2356.

[25] Crudele J., Chamberlain J.:AAV-based gene therapies for the muscular dystrophies. Hum Mol Genet. 2019; 28(R1): R102-R107.

[26] Xu R., Jia Y., Zygmunt D.A., et al.: rAAVrh74.MCK.GALGT2 Protects against Loss of Hemodynamic Function in the Aging mdx Mouse Heart. Mol Ther. 2019; 27(3): 636-649.

[27] Min Y., Bassel-Duby R., Olson E.: CRISPR Correction of Duchenne Muscular Dystrophy. Annu Rev Med. 2019; 70: 239-255.

[28] Urszula Fiszer [red], Podstawy neurologii z opisami przypadków klinicznych, Termedia Poznań 2010: 232-234.

[29] Mendell J., Chicoine L., Al-Zaidy S., et al.: Gene Delivery for Limb-Girdle Muscular Dystrophy Type 2D by Isolated Limb Infusion. Hum Gene Ther. 2019; 30: 794-801.

[30] Sahenk Z., Ozes B.: Gene therapy to promote regeneration in CharcotMarie-Tooth disease. Brain Res. 2020; 1727: 146533.

[31] Timchenko L.: Correction of RNA-Binding Protein CUGBP1 and GSK3 Signaling as Therapeutic Approach for Congenital and Adult Myotonic Dystrophy Type 1. Int J Mol Sci. 2019; 21: 94. 